\title{
TREATMENT OF TYPHOID FEVER BY INTRAVENOUS INJECTIONS OF POLYVALENT SENSITIZED TYPHOID VACCINE SEDIMENT
}

\author{
STUDIES IN TYPHOID IMMUNIZATION VI* \\ FREDERICK P. GAY, M.D. \\ BERKELEY, CALIF. \\ AND \\ HENRY T. CHICKERING, M.D. \\ ROCKEFELLER HOSPITAL, NEW YORK
}

Since the work of Fraenkel $^{1}$ in 1893, killed preparations of the typhoid bacillus have been injected subcutaneously as a means of treatment in typhoid fever. Little interest was at first awakened by the suggestive results of Fraenkel except in a discussion of the specificity of his treatment (Rumpf,, ${ }^{2}$ Kraus and Buswell, ${ }^{3}$ Presser. ${ }^{4}$ ) In 1902 Petruschy ${ }^{5}$ used a combination of vaccine and immune serum in typhoid, and in 1908 Pescarolo and Quadrone ${ }^{6}$ advocated the use of a living, avirulent typhoid culture. Following the interest in vaccine therapy awakened by Wright, increasingly frequent reports on the possible value of typhoid vaccines in typhoid fever have appeared. In 1912 Callison $^{7}$ summarized the results obtained by numerous authors, chiefly English and American, in 747 cases, and in 1915 Krumbhaar

\footnotetext{
* Submitted for publication Nov. 29, 1915.

* From the Hearst Laboratory of Pathology and Bacteriology, University of California.

* For previous studies see: The Archives Int. Med., 1913, xii, 613; 1913. xii, 622 ; 1914, xiii, 471; 1914, xiv, 662; 1914, xiv, 671. This work was rendered possible by a donation for research from an alumnus of the University of California, and further facilitated by a grant from the Rockefeller Institute for Medical Research.

1. Fraenkel, E.: Ueber spezifische Behandlung des abdominal Typhus, Deutsch. med. Wchnschr., 1893, xix, 985.

2. Rumpf, T.: Die Behandlung des Typhus abdominalis mit abgetodteten Cultures des bacillus Pyocyaneus, Deutsch. med. Wchnschr., 1893, xix, 987.

3. Kraus, F., and Buswell, H. C.: Ueber die Behandlung des Typhus abdominalis mit abgetodteten Pyocyaneus Culturen, Wien. klin. Wchnschr., 1894, vii, 511,595 .

4. Presser, L.: Ueber die Behandlung des Typhus abdominalis mit Injektionen von Culturflüssigkeiten von Bac. Typhi und Bac. Pyocyaneus, Ztschr. f. Heilk., 1895, xvi, 113.

5. Petruschy, J.: Spezifische Behandlung des abdominal Typhus, Deutsch. med. Wchnschr., 1902, xxviii, 212.

6. Pescarolo, B., and Quadrone. C.: Aktiv Immunisation durch subcutane Injektionen lebenden Typhus bazillen bei Eberthscher Infektion, Zentralbl. $\mathrm{f}$. inn. Med., 1908, xxix, 989.
}

7. Callison, J. G.: The Therapeutic Use of Vaccines in Typhoid Fever, Am. Jour. Med. Sc., 1912, cxliv, 350. 
and Richardson ${ }^{8}$ could collect over 1,800 cases reported on by forty authors. It is known that many physicians, and probably an increasing number of them, use vaccines in typhoid because they find they do no harm and they believe them to do some good. The best studied groups of cases treated in this manner, however, give ground for little unrestrained enthusiasm, and certainly no claim that any such type of specific therapy has been attained as is the case in diphtheria and epidemic meningitis. The best that may be said is that the ordinary type of killed typhoid vaccine administered subcutaneously in controlled groups of cases may cause a shortening of the course of the disease, a lower mortality, and perhaps fewer relapses and complications. We purposely refrain from further analysis of the ordinary type of vaccine therapy which has been described, since we are to deal with methods and results which we believe constitute a new era in the specific treatment of typhoid fever.

In the last few months reports on the intravenous injection of ordinary heat-killed vaccine (Thiroloix and Bardon, ${ }^{9}$ Kraus and Mazza $^{10}$ ) and particularly on the intravenous injection of sensitized vaccines (Ichikawa ${ }^{11}$ ) in typhoid fever, have led us to anticipate a far more hopeful future in combating this disease than has hitherto seemed likely. Before proceeding to a consideration of the results recorded by several authors in actual cases, we may be pardoned for repeating the experimental evidence by which we were led to a practical consideration of this problem before most of these observations were made.

In a previous article in this series Gay and Claypole ${ }^{12}$ described a new and specific form of hyperleukocytosis which occurs in immunized rabbits on intravenous reinjection of the specific antigen (bacteria, red blood cells, serum). We found, for example, that the injection of living typhoid bacilli, or of typhoid vaccine in a typhoid immune rabbit, caused the leukocytes to fall in the first two or three hours and then to rise to critical levels that occurred at about the twelfth and again at the twenty-eighth hour. At the latter period leukocyte counts of 150,000 per cubic millimeter were not uncommon, a surprising rise from the normal count of from 8,000 to 12,000 , and one that has not been

8. Krumbhaar and Richardson: The Value of Typhoid Vaccine in the Treatment of Typhoid Fever, Am. Jour. Med. Sc., 1915, cxlix, 406.

9. Thiroloix and Bardon: Vaccin Typhique intraveineux, Centralbl. f. Bakt. Ref., 1914, 1x, 212 (3d ref.).

10. Kraus, R., and Mazza, S.: Zur Frage der Vakzinetherapie des Typhus abdominalis, Deutsch. med. Wchnschr., 1914, x1, 1556.

11. Ichikawa, S.: Mitteil. d. med. Gesellsch., zu. Osaka, April. 1912, x. No. 5; Abortive Treatment of Typhoid and Paratyphoid, Sei-I-Kwai Med. Jour.. Tokyo, 1914, xxxiii, No. 12, p. 73, or Ztschr. f. Immunitätsforsch., 1914, xxiii, 32.

12. Gay, F. P., and Claypole, E. J.: Specific Hyperleukocytosis: Studies in Typhoid Immunization, IV, The Archives Int. Med., 1914, xiv, 662. 
attained, so far as we are aware, by other experimental methods. These hyperleukocytic crises, moreover, are coincident with the destruction of the typhoid bacillus in the immune animal, and would appear to be the cause of it. The same dose of typhoid bacilli in a normal rabbit produces a distinct but markedly lower grade of hyperleukocytosis. We logically regarded the extreme grade of hyperleukocytosis as dependent on the presence of antibodies (tropins) in the immune animal, an hypothesis that we were able to verify by obtaining similar results in normal rabbits by the use of tropinized (sensitized) cultures of $B$. typhosus; that is to say, cultures that had been treated with an immune serum. From these experiments it seemed reasonable to express the opinion that the intravenous injection of sensitized typhoid vaccine offered a possibly successful method of treating typhoid fever. ${ }^{13}$ As a preliminary to the intended application of the sensitized typhoid vaccine sediment, which we advocate for prophylactic use against typhoid fever, ${ }^{14}$ in the treatment of this disease, we tested its curative effect in rabbits that had been made "carriers" of the typhoid bacillus. ${ }^{15}$ A few of these animals were apparently freed of the typhoid bacillus by the intravenous injection of the sensitized vaccine; that a majority of them remained unaffected is due to the inaccessibility of the microorganism in the gallbladder of such carrier rabbits. Further preliminary experiments have shown us that relatively large doses of sensitized typhoid vaccine can be given with safety directly into the circulation of rabbits and monkeys, and even when these animals have been partially immunized against $B$. typhosus. The latter condition, owing to the presence of agglutinins, was aimed to simulate the condition in typhoid fever. ${ }^{16}$

On the basis of this experimental evidence accumulated in 1913 and 1914 , we were prepared to attempt treatment of human cases, but no opportunity presented itself until early in 1915. Since February of this year we have been privileged to examine over 100 cases of clinically suspected typhoid, to carry out in most of them our own laboratory examinations, and to cooperate in the treatment of the great majority of them in which a diagnosis of typhoid fever could be fully confirmed.

13. Gay, F. P., and Claypole, E. J.: Specific Hyperleukocytosis: Studies in Typhoid Immunization, IV, The ARChives Int. MED., 1914, xiv, 669.

14. Gay, F. P., and Claypole, E. J.: An Experimental Study of Methods of Prophylactic Immunization Against Typhoid Fever: Studies in Typhoid Immunization, V, The Archives Int. Med., 1914, xiv, 671.

15. Gay, F. P., and Claypole, E. J.: The "Typhoid Carrier" State in Rabbits as a Method of Determining the Comparative Immunizing Value of Preparations of the Typhoid Bacillus: Studies in Typhoid Immunization, I, ThE Archives Int. Med., 1913, xii, 613.

16. It may be of interest to note in this connection that efforts made to produce typhoid carriers in Macacus rhesus monkeys by injecting large doses of living culture directly into the circulation have failed. 
This study has been made possible by the hearty interest and cooperation of over fifty physicians in Berkeley, Oakland, San Francisco and their environs. ${ }^{17}$

We may now proceed to a brief discussion of the results of other investigators who have made use of the recent innovations in the vaccine treatment of typhoid, leaving analysis of details of method and result for comparison with our own records. Recent results with subcutaneous injection of unsensitized vaccine are purposely omitted, however favorable.

Sensitized Typhoid Vaccines Employed Subcutaneously.Besredka ${ }^{18}$ suggested in 1902 the use of dead or living bacteria that had previously been treated with an immune serum, the excess of which was subsequently removed, as means of producing active immunity without severe reaction. In 1911 Metchnikoff and Besredka ${ }^{19}$ on the basis of experiments on anthropoid apes, advocated the use of living sensitized typhoid vaccines as the best prophylactic against typhoid fever and their subsequent results ${ }^{20}$ would seem to indicate that they are as good or better than the ordinary vaccine for this purpose. These living sensitized cultures have also been employed subcutaneously in the treatment of typhoid fever during the last few years by several French observers. We find reports by Ardin-Delteil, Negre and Raynaud,21 Boinet,, ${ }^{22}$ Deléarde and Leborgne, ${ }^{23}$ Sablé,, ${ }^{24}$

17. We wish to express our deepest appreciation to the following physicians who have placed cases at our disposal for this study: Drs. E. N. Ewer, Dudley Smith, George L. Reinle, C. A. DePuy, E. M. Lundegaard, C. A. Queirolo, A. Liliencrantz, Guy H. Liliencrantz, M. L. Emerson, A. F. Clarke, W. H. Irwin, E. A. Majors, H. A. Mackinson, A. M. Shade, C. S. Powell, C. H. Rowe, E. G. Simon, C. R. Krone, F. M. Sylvester, A. S. Kelly, J. M. Shannon, W. H. Streitmann, E. von Adelung and P. F. Abbott of Oakland; Frank W. Simpson, May H. Sampson, Robert Hector, A. M. Meads, L. A. Martin, F. H. Van Tassell, J. J. Benton. J. M. Beuckers, H. S. Delamere, M. F. Toner, R. Paroni, R. T. Legge, H. W. Crane, Sheffield; W. A. Wood, T. C. McCleave of Berkeley; J. K. Hamilton, R. E. Burns and H. M. Pond of Alameda; H. C. Miller, C. A. Wills of San Leandro;. H. C. Moffitt, Wm. P. Lucas, Geo. E. Ebright, P. K. Brown, Chas. A. Pauson, Fred G. Burrows, R. L. Wilbur, G. H. Evans, and R. D. MacKinnon, San Francisco; and L. L. Stanley, San Quentin.

18. Besredka, A.: De l'immunisation active contre la peste, le cholera et l'infection typhique, Ann. d. l'Inst. Pasteur, 1902, xvi, 918.

19. Metchnikoff, E., and Besredka, A.: Réchérches sur la fiévre typhoide experimentale, Ann. de 1'Inst. Pasteur, 1911, xxv, 193; Des vaccinations antityphiques, Ibid., p. 865.

20. Metchnikoff, E., and Besredka, A.: Des vaccinations antityphiques, Ann. de 1'Inst. Pasteur, 1913, xxvii, 597.

21. Ardin-Delteil, Negre, L., and Raynaud, Maurice: Sur la vaccinotherapie de la fiévre typhoide, Compt. rend Acad. d. sc., 1912, clx, 1174; Recherches sur les reactions humorales des malades atteints de fiévre typhoide traités par le vaccin de Besredka, Compt. rend Soc. de biol., 1913, lxxiv, 371.

22. Boinet: Vaccinotherapie de la fiévre typhoide par le virus sensibilisé de Besredka, Compt. rend. Soc. de biol., 1913, lxxiv, 507.

23. Delearde and Leborgne: Province méd., June 21, 1913, p. 273.

24. Sablé: Jour. d. sc. méd. de Lille, July, 1913, No. 38, p. 25 ; No. 29 , p. 49. 
Netter, ${ }^{25}$ Roques $^{26}$ and Alfaro, ${ }^{27}$ Feistmantel ${ }^{28}$ and Garbat ${ }^{29}$ have employed other preparations of killed sensitized vaccines. In these, as in the later cases, the criteria of improvement differ with individuals and are hard to compare.

Unsensitized Vaccine Administered Intravenously.-Several different preparations of killed typhoid vaccine have been tried intravenously but Vincent's polyvalent ether-killed autolysate has been used in the greatest number of cases. Following the brief communication of Thiroloix and Bardon ${ }^{9}$ in 1913, articles have appeared by Kraus and Mazza, ${ }^{10} \mathrm{Kraus}^{30}{ }^{30}$ Biedl, ${ }^{31}$ Csernel and Marton, ${ }^{32}$ Rhein, ${ }^{33}$ Reibmayr, ${ }^{34}$ Mazza, $^{35}$ Holler, ${ }^{36}$ Löwy, Lucksch and Wilhelm, ${ }^{37}$ Paulicek, ${ }^{38}$ Ditthorn and Schultz ${ }^{39}$ and McWilliams. ${ }^{40}$ This intravenous injection of typhoid vaccine gives a definite reaction which if certain limits of dosage are exceeded may be alarming or dangerous. We shall consider this reaction in more detail later.

Sensitized Vaccine Administered Intravenously.-So far as we are aware, three types of sensitized typhoid vaccine have been employed

25. Netter: Bull. et mém. Soc. méd d. hôp., July 24, 1913, p. 126.

26. Roques: Contribution a l'étude de la vaccinotherapie de la fiévre typhoide par le virus-vaccin sensibilisé antityphique vivant de Besredka, Thèses University of Toulouse, 1913, Ed. Ch. Dirion.

27. Alfaro, A.: Rev. Soc. Med. Argentina, 1913, p. 683.

28. Feistmantel, C.: Ueber Prophylaxie und Therapic des Typhus Abdominalis mittels Impfstoffen, Wien. klin. Wchschr., 1915, xxviii, 230.

29. Garbat, A. L.: Sensitized Versus Nonsensitized Typhoid Bacteria in the Prophylaxis and Treatment of Typhoid Fever, Jour. Am. Med. Assn., 1915, 1xiv, 489.

30. Kraus, R.: Bemerkungen ueber Schutzimpfungen und eine Bakteriotherapie des Typhus abdominalis, Wien. klin. Wchnschr., 1914, xxvii, 1443.

31. Biedl, A.: (Letter to Paltauf) Zur Vakzinetherapie des Typhus abdominalis, Wien. klin. Wchnschr., 1915, xxviii, 125; Therapeutische Verwendung von Typhus-Impfstoffen beim Menschen, Prag. med. Wchnschr., 1915, x1, 53.

32. Csernel, E., and Marton, A.: Die Therapie des abdominal Typhus mit nicht sensibilisieter Vakzine, Wien. klin. Wchnschr., 1915, xxviii, 229; Die Behandlung des typhus abdominalis mit nicht sensibilisieter Vakzine, Ibid., p. 733.

33. Rhein, M.: Zur Bakteriotherapie des Typhus abdominalis, München. med. Wchnschr.; 1915, 1xii, 427.

34. Reibmayr, H.: Ueber Impfstoffbehandlung des Typhus abdominalis auf intravenösem Wege, München. med. Wchnschr., 1915, lxii, 610.

35. Mazza, S.: Die Bakteriotherapie des Typhus abdominalis, Wien klin. Wchnschr., 1915, xxviii, 64.

36. Holler, G.: Zur Vakzinetherapie des Typhus abdominalis, Ztschr. f. klin. Med., 1915, 1xxxi, 462; Erfahrungen über Bakteriotherapie des Typhus abdominalis, Med. klin., 1915, xi, 639 and 668.

37. Löwy, R., Lucksch, F., and Wilhelm, E.: Zur Vakzinetherapie des Typhus abdominalis, Wien. klin. Wchnschr., 1915, xxviii, 756.

38. Paulicek, E.: Zur Frage der Typhusheilimpfungen, Wien. klin. Wchnschr., 1915. xxviii, 759 .

39. Ditthorn, F., and Schultz, W.: Zur Antigenbehandlung des Typhus, Med. Klin., 1915, xi, 100.

40. McWilliams, H. I.: Treatment of Typhoid Fever with Typhoid Vaccine Administered Intravenously, New York Med. Rec., Oct. 16, 1915, p. 648. 
for intravenous administration in typhoid fever. Ichikawa, ${ }^{11}$ who began this type of treatment (1913), used recent cultures of $B$. typhosus sensitized by the serum of patients recovering from typhoid fever and killed, or at least attenuated, by the addition of phenol. A similar method has been employed by Koranyi. ${ }^{41}$ A considerable series of cases have since been treated by Biedl, ${ }^{31}$ Eggerth, ${ }^{42}$ Sladek and Kotlowski, ${ }^{43}$ Boral, ${ }^{44}$ Holler, ${ }^{76}$ Löwy, Luksch and Wilhelm, ${ }^{37}$ and $\mathrm{F}$. Meyer, ${ }^{45}$ who, for the most part, have employed the Besredka living sensitized vaccine.

Any comparison of the results of treatment by these three most recent methods on the basis of percentage benefited, is at best only of suggestive value. As already stated, the criteria on which an estimation of benefit is based vary and no absolute standard is possible, nor do mortality figures offer any conclusive results, but they may be added for completeness since they are at least more definite than any estimated benefit. Since many of the deaths in typhoid are, properly speaking, - accidental (hemorrhage, perforations) they cannot be used correctly as criteria of the efficiency of treatment, particularly in those patients that are treated fairly late in the disease where such evolving lesions could not reasonably be affected.

Table 1.- Summary of Recent Cases of Typhoid Fever Reported as Treated by Newer Methods of Vaccine Treatment

1. Cases treated by subcutaneous injection of sensitized vaccine....

2. Cases treated by intravenous injection of untreated vaccine....

3. Cases treated by intravenous injection of sensitized vaccine...

$\begin{array}{cccc}\text { Authors } & \begin{array}{c}\text { Number } \\ \text { Cases }\end{array} & \begin{array}{c}\text { Benefited } \\ \text { Per Cent. }\end{array} & \begin{array}{c}\text { Mortality } \\ \text { Per Cent. }\end{array} \\ 11 & 253 & 57 . \dagger & 7.1 \\ 14 & 259 & 63 . & 19 . * \\ 8 & 207 & 81.8 & 9.6\end{array}$

* Due in part to inclusion of a large number of war cases by Paulicek ${ }^{38}$ where delayed transportation from the front increased mortality.

† Of 201 cases.

This summary would suggest that the best method of treatment of the three would be the intravenous injection of living sensitized vaccine as based on a higher percentage of benefit and lower mortality than the intravenous injection of unsensitized vaccine. Individual reports would

41. Koranyi, A. V.: Zur Vakzinebehandlung des Typhus abdominalis, Wien. klin. Wchnschr., 1915, xxviii, 85.

42. Eggerth, H.: Zur Vakzinetherapie des Typhus abdominalis, (Letter published by Paltauf), Wien. klin. Wchnschr., 1915, xxviii, 126.

43. Sladek, J., and Kotlowski, St.: Zur Vakzinetherapie des Typhus abdominalis, Wien. klin. Wchnschr., 1915, xxviii, 389.

44. Boral, H.: Beitr. zur Frage der Typhustherapie mit Besredka-Vakzine, Wien. klin. Wchnschr., 1915, xxviii, 415.

45. Meyer, F.: Spezifische Typhusbehandlung, Berl. klin Wchnschr., 1915, lii, 677 . 
indicate that this difference is really more marked than the summary would show, owing to the fact that the benefit in the third category is more likely to be in the nature of an abortive cure with critical fall of temperature rather than a gradual amelioration and lysis of the fever. Moreover, several authors who have used two or more of the methods do not hesitate unanimously to favor the intravenous over the subcutaneous method and sensitized vaccine over the unsensitized. (Holler, ${ }^{36}$ Thiroloix and Bardon, ${ }^{9}$ Biedl, ${ }^{31}$ Meyer, ${ }^{45}$ Löwy, Lucksch and Wilhelm. ${ }^{37}$ )

\section{PERSONAL CASES}

Owing to the irregular conditions under which our cases occurred in the hospital or home practice of a number of different physicians, it has been necessary for our own records to esablish the diagnosis to our own satisfaction by a uniform method. It has also been a pleasure to be able to cooperate in a relatively large number of cases in the differential diagnosis of typhoid fever from other infections, on the basis of laboratory examinations. Although there is no need of defending the value of laboratory methods as aiding in the diagnosis of typhoid fever, it may still be pertinent to express the value of a complete series of negative examinations as tending to exclude typhoid even in the presence of a temporary clinical appearance of the disease. This is particularly important in view of the fact that the laboratory diagnosis in general practice depends almost entirely on a Widal reaction alone, and that often performed in a not wholly accurate manner. We wish, incidentally, therefore, to contribute our laboratory results in the differential diagnosis of typhoid, before considering the treatment of those cases in which the diagnosis was positive.

We have carried out laboratory examinations on 105 cases of suspected typhoid fever which may be subdivided as follows:

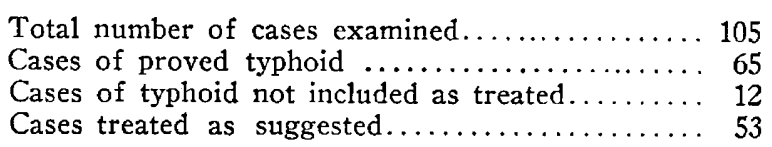

Method of Laboratory Examination.-With few exceptions in the earlier part of the investigation, the routine laboratory examination of each case has been as follows:

1. Blood Culture.-Ten c.c. of blood, taken from a vein at the elbow, after proper preparation of the skin with iodin, are mixed with 200 c.c. of 10 per cent. bile broth. In a number of cases the relative intensity of the bacteriemia was estimated by plating 1 or 2 c.c. in melted agar (10 c.c.). The broth cultures were examined daily to the tenth day or until positive. Organisms of correct morphology for the typhoid bacillus were identified by the usual cultural methods in several sugars (glucose and lactose particularly) and in litmus milk. Final diagnosis of a suspected organism depended on agglutination by an antityphoid serum of high potency.

2. Widal.-Two to 5 c.c. of blood were placed in a sterile conical centrifuge tube and allowed to clot. By centrifugalization the serum could then soon 
be separated and freed from the blood cells. A series of dilutions beginning 1:10 in a total volume of 1 c.c. of saline was then made running usually to 1:640 or higher when indicated. To each tube there was then added a drop of a thick standard saline suspension of a stock strain of B. typhosus grown on agar bottles in large amount and killed and preserved by the addition of 0.1 per cent formaldehyd (40 per cent.). A positive reaction is present in a few hours at room temperature in the lower dilutions, but the final results are read from complete sedimentation of the bacteria with clear supernatant fluid on the following day. This type of macroscopic test gives no pseudo reactions even in a dilution of $1: 10$ and very rarely to a prezone of inhibition. This low dilution therefore may be regarded as diagnostic of typhoid fever (except in vaccinated cases).

In the few cases in which both Widal and blood culture were negative, the typhoid bacillus was sought for in stools and urine.

Method of Isolation of B. Typhosus from Stools and Urine.-The well known method of smearing direct from stools on successive litmus lactose agar plates was employed. After incubation, suspicious transparent blue colonies were then transferred to agar and sub-cultures made on glucose and lactose media and on litmus milk. Agglutination tests with anti-typhoid serum and paratyphoid "a" and "b" serum of known titer were then made. Enriching with 10 per cent. bile broth was also tried, a loopful of the liquid part of the stool or 1 c.c. of urine being added to 5 c.c. of bile broth. Subsequently plates were made as before.

Cases of Proved Typhoid.-Of the sixty-five cases accepted as typhoid on the basis of laboratory examination, the Widal was positive in sixty (93.7 per cent.), including cases in which the examination was made as early as the fifth day. Of blood cultures taken in fifty-eight of these cases there were forty positive ( 70 per cent.) including cases taken as late as the thirty-second day.

In One Case Only of this Series were Both Widal and Blood Culture Negative.-In this case the diagnosis was based on the presence of B. typhosus in the stools.

In this series of sixty-five cases are included two cases of infection due to B. paratyphosus "b," one of which was treated and one of which refused treatment by the method to be described.

Cases of Proved Typhoid That Were Not Treated.-There are twelve cases among the sixty-five of proved typhoid that were not included among the treated patients for the following reasons:

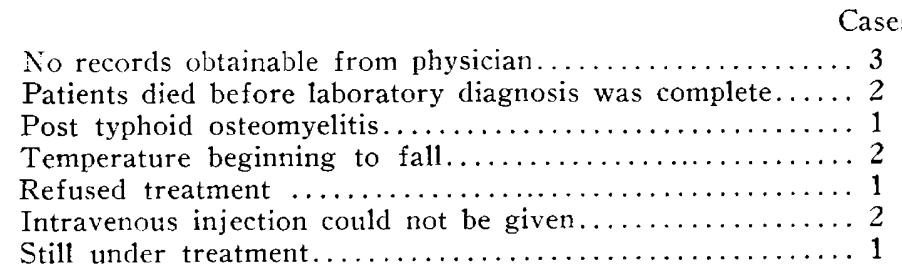

These cases are mentioned to emphasize the fact that no choice was exercised in the cases treated. In every case in which the diagnosis was certainly typhoid the patient was treated if possible except in the 
instances in which a falling temperature might lead to an unc'arranted conclusion of benefit produced by the treatment.

There remain forty patients examined in which the clinical diagnosis of suspected typhoid could not be confirmed by laboratory examinations. It is of interest to note that none of these patients gave a positive Widal in dilution of $1: 10$ by the method described. The blood cultures were negative in all. In five of the clinically more promising cases the stools and urine were also negative. From the point of view of the accuracy of the laboratory examinations it is of interest to note that on the basis of further laboratory examinations and their clinical course, thirty-six could be excluded as definitely not typhoid. From their interest in the matter of differential diagnosis it may be of value to catalogue these cases as follows:

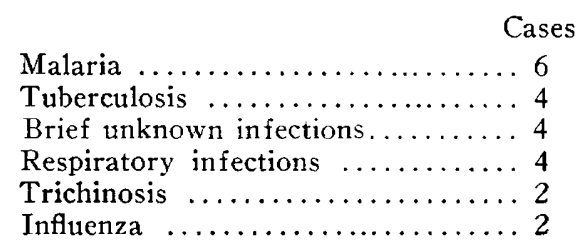

and one each of the following: Infection following abortion, erysipelas, tonsillitis, measles, prostatitis, postoperative infection of the nose, appendicitis, pleurisy, coryza, pharyngitis, normal, endocarditis, cystitis, constipation.

There remain then four cases which, on the basis of excellent clinical evidence alone and in absence of confirmatory laboratory proof, may still from one point of view be classed as typhoid. These cases are not included in our treated series on the ground of not being certainly proved typhoid. It may be remarked, however, that two of these patients were treated and both recovered abruptly with a single intravenous injection of our vaccine. They would, therefore, if added to our series, simply increase the percentage of favorable results.

We have then a series of fifty-three cases of typhoid fever in which the clinical diagnosis was fully verified by laboratory examination and in which it was possible to carry out specific treatment as intended. Owing to the extremely variable conditions under which these cases have been studied, both in hospitals and homes, it has been manifestly impossible in many instances to carry out as complete examinations from the laboratory point of view as could be desired. The general conduct of the cases from the point of view of diet, hydrotherapy and other palliative measures, we have not been able, or, indeed, wished to control. The variations, then, from the standpoint of general treatment are precisely those which one might expect from the logically different conceptions of the disease found in any group of fifty physicians. The 
conduct of the vaccine treatment has, however, owing to the uniform courtesy of those who have allowed us the privilege of this study, been developed from our own experience and the interpretations are again our own. We can only feel that if a similar group of cases could be studied and treated under a uniform set of conditions, that the undoubtedly beneficial results which we attribute to this specific treatment would only be enhanced.

\section{METHOD OF TREATMENT}

The typhoid vaccine we have used in the treatment of these cases of typhoid fever is one that has already been advocated for the prophylactic immunization of human beings by Gay and Claypole. ${ }^{14}$ It consists of the ground sediment of a mixed polyvalent vaccine that has been sensitized by an antityphoid serum and then killed and precipitated by alcohol. From this ground culture the endotoxins are extracted by carbolated saline solution and the remaining sediment of bacterial bodies alone used. On the basis of experimental results this vaccine was found to be superior for protecting rabbits against infection with the typhoid bacillus as compared with other types of vaccine commonly employed, including Besredka's living sensitized vaccine. In the practical use for prophylactic purposes of this vaccine in man it has been shown that it produces less symptomatic disturbance on inoculation $\left(\right.$ Force $^{46}$ ) and may be regarded as more protective against typhoid fever in civil communities than several other types of commercial vaccine (Sawyer ${ }^{47}$ ) as judged by the incidence of typhoid fever among the vaccinated. That the protection afforded by this vaccine employed in civil communities is relative and not so perfect as that hitherto obtained in the United States Army we do not regard as proof that this vaccine may not be as superior to other types of vaccine, including Army vaccine, in practical civil conditions of human infection, as our experimental results in animals would lead us to expect.

This polyvalent, sensitized typhoid vaccine sediment is administered for prophylactic purposes in doses of a suspension of $1 / 10 \mathrm{mg}$. of dried bacteria, which corresponds to an original bacteria count of about 750 millions. Such a dose when given subcutaneously in a normal individual very rarely produces more than a slight local reaction. For therapeutic purposes we have given doses intravenously ranging from $1 / 100$ to $1 / 10 \mathrm{mg}$., most of the doses being between $1 / 50$ and $1 / 25 \mathrm{mg}$. ( 150 to 300 million bacteria). Such a dose when administered intravenously produces a series of distinct symptoms which vary

46. Force, J. N.: Institutional Vaccination Against Typhoid Fever, Am. Jour. Pub. Health, 1913, iii, 750.

47. Sawyer, W. A.: The Efficiency of Various Antityphoid Vaccines, Jour. Am. Med. Assn., 1915, Ixv, 1413. 
markedly in intensity with individuals and which are apparently similar in normal and typhoid cases. Although our symptoms are like those described by recent writers who have used the intravenous method for either sensitized or unsensitized dead cultures, it is reasonable to assume that in aliquot parts our vaccine should be less toxic owing to the abstraction of the endotoxins from the ground bacteria. This lesser toxicity seems to have been proved by our results. Although the upper range of doses mentioned may provoke alarming symptoms in the more susceptible individuals, it may be stated at once that in over 150 doses which we have administered no eventual or even temporary harm seems to have been done to the patient. It seems necessary to produce a moderate reaction to bring about the desired results. Before discussing the symptoms that have been noted we may present the record of a typical severe reaction produced in a normal individual who volunteered for the purpose.

S. B. H., male, aged 27 , had never had typhoid fever or been vaccinated against typhoid. In good health. Oct. 28, 1915, given 180 million sensitized vaccine intravenously.

Leukocyte count before the injection, 6,600; polymorphonuclears, 54 per cent.; lymphocytes, 28 per cent.; large mononuclears, 18 per cent. Temperature, $100 \mathrm{~F}$.

One half hour after injection patient had a general shaking chill lasting thirty minutes. Patient was not cyanotic but had slight respiratory distress due to muscle spasm. Patient vomited twice after chill was over. Temperature rose gradually to a maximum of 104.4 three hours after injection and then fell to 102.4 at the fifth hour and 97.6 at the tenth hour. It had returned to 99.2 in twenty hours, where it remained. Pulse rose to 120.

Leukocyte counts following injection were as follows:

\begin{tabular}{|c|c|c|c|c|c|}
\hline & & $\begin{array}{l}\text { Polys. } \\
\text { Per }\end{array}$ & $\begin{array}{l}\text { Lymphs. } \\
\text { Per } \\
\text { Cent. }\end{array}$ & Large & \\
\hline Hours After & No. & Cent. & Cent. & Monos. & $\begin{array}{c}\text { Eosin } \\
. .\end{array}$ \\
\hline $\begin{array}{l}\text { One } \ldots \ldots \ldots \ldots \ldots \ldots \\
\text { Three } \ldots \ldots \ldots \ldots \ldots \ldots\end{array}$ & $\begin{array}{l}4,200 \\
7,900\end{array}$ & $\begin{array}{l}70 \\
88\end{array}$ & $\begin{array}{r}22 \\
6\end{array}$ & $\begin{array}{l}8 \\
6\end{array}$ & $\begin{array}{l}\cdots \\
\cdots\end{array}$ \\
\hline Five $\ldots \ldots \ldots \ldots \ldots$ & 8,800 & 89 & 6 & 5 & $\cdots$ \\
\hline Ten ... & 12,000 & 80 & 10 & 10 & . \\
\hline Twelve. & 12,200 & 75 & 11 & 14 & - \\
\hline Fourteen & 15,400 & 71 & 16 & 13 & \\
\hline Sixteen & 16,600 & 52 & 15 & 32 & 1 \\
\hline Eighteen & 14,000 & 74 & 8 & 18 & .. \\
\hline Twenty ... & 12,000 & 60 & 17 & 23 & \\
\hline Twenty-two & 11,000 & 50 & 6 & 44 & . \\
\hline Thirty-six. & 11,600 & 25 & 22 & 52 & 1 \\
\hline Sixty .... & 11,000 & 42 & 27 & 31 & . \\
\hline
\end{tabular}

This reaction in a normal individual is similar to the one produced in a case of typhoid fever, though distinctly more severe than the average.

A composite picture of the train of symptoms that follows the intravenous injection of our sensitized vaccine given in proper dosage is as follows: 
A chill occurs beginning in one half hour to one hour and lasting from a few minutes to ten or fifteen. This chill is accompanied by a rise in temperature of 1 to 3 degrees, which reaches its height within three hours after injection, and then falls. There may be a rise of temperature without chill. The rise in temperature is accompanied by a leukopenia as low as 2,000 to 3,000 per cubic millimeter, which may be preceded by a very transitory hyperleukocytosis during the chill. The chill is accompanied by an increase in the pulse rate (say to 120 ). Slight cyanosis, slight respiratory distress and frequently discomfort may occur.

The fall in temperature reaches normal or subnormal (as low as 94 F. per rectum) in about twelve hours. This fall in temperature is accompanied by sweating, which may be profuse and last for several hours, relaxation, and usually general amelioration of such symptoms as headache, delirium and the like. The patient often feels perfectly well and demands food and even when this condition is transitory it would seem to be beneficial. Coincidently there is a rise in leukocytes which may reach as high as 40,000 and frequently 15,000 to 20,000 . This is represented by a relative polymorphonuclear increase of 80 to 90 per cent. This hyperleukocytosis is the more striking in view of the characteristic leukopenia of typhoid. This particular reaction, which we regard as of peculiar significance, was predictable from our experimental results in rabbits and mentioned in a preliminary communication. ${ }^{48}$ It has since been touched on by Holler ${ }^{36}$ and confirmed fully by $\mathrm{McW}$ illiams. ${ }^{40}$

In four instances we feel that the dose administered was too large for the individual case and in such instances there may be vomiting, cyanosis and even symptoms of collapse, with irregular heart action. In one case in which 800 million were given by another's mistake, there was partial collapse and small hemorrhages in the mouth reported.

The possible dangers of the intravenous method of treatment, whether with unsensitized or with sensitized vaccines, have been mentioned by a number of recent authors. It should be stated that unfavorable reports are based on the use of vaccines more toxic than the one we have employed and the criticisms when severe have been based on a very limited experience. Thus Boral ${ }^{44}$ had a single patient who died three days after intravenous injection of the Besredka vaccine, in which case the outcome was attributed, for no specific reason, to the vaccine. Sladek and Kotlowski ${ }^{43}$ urge caution owing to possible danger of collapse. Deutsch ${ }^{49}$ had one patient who died with meningeal

48. Gay, F. P.: Abortive Treatment of Typhoid Fever by Sensitized Typhoid Vaccine Sediment, Jour. Am. Med. Assn., 1915, 1xv, 322.

49. Deutsch, F.: Zur Vakzinebehandlung des Typhus abdominalis, Wien. klin. Wchnschr., 1915, xxviii, 810 . 
symptoms five days after treatment. Bied1 ${ }^{31}$ noted increase of epistaxis in two of his patients. Csernel and Marton ${ }^{32}$ believe the intravenous injections are contraindicated in hemorrhage, perforation, cholecystitis and cases with irregular heart action. It seems evident that with growing experience the danger decreases (Koranyi ${ }^{\mathbf{4 1}}$ ) and we are inclined to believe with Holler ${ }^{36}$ that the danger lies not so much in the method as in the physician who administers the vaccine. Of the authors mentioned, it is interesting to note that only one (Deutsch) really abandoned the intravenous route.

It would seem evident from the symptoms that we have described that great caution should be used in choosing the dose to be employed with particular regard to the existence of such existing complications as abnormal cardiac functioning and hemorrhage. We have not seen any contraindication in the presence of slight bronchial or bronchopneumonic involvement and have proceeded cautiously with the treatment in four such cases. We have further treated one patient in whom hemorrhage had begun without increasing it.

No detailed method of procedure can be prescribed in treating a given case of typhoid fever by our sensitized sediment. The best results seem to be obtained by provoking a distinct but not too severe reaction of the type outlined, characterized particularly by a temperature excursion and hyperleukocytosis. The dose necessary to produce such a result varies markedly with the individual and with the particular balance already established between the infecting agent and resisting host. A single injection may be all that is necessary to restore the individual to an essentially normal condition as judged from the temperature chart; and as has been mentioned, the subjective symptoms follow the fever. The temperature may drop to normal following the initial rise and remain there, in which case no further injections are necessary, except perhaps to prevent relapse. As a rule, however, the most favorable type of rapid return to normal is a matter of two or three days instead of twenty-four hours, and we have usually waited this longer period before repeating the treatment.

We had best leave further discussion of the variations in method of treatment until we have given our results as a whole, together with such correlations as present themselves between the results produced and the blood findings before and after injection.

Our cases may be readily divided in respect to results, into three rather sharply defined groups, which we herewith exemplify by the appended type charts. (Figs. 1-3).

Group I. Relatively Unaffected Cases.-This group comprises eighteen, or 34 per cent. of our cases. Each and all of the successive treatments in these cases, although frequently resulting in temperature 
excursion, hyperleukocytosis, and the other symptoms, apparently produce no permanent result so far as shortening the course of the disease is concerned. It is not strictly speaking exact to classify these as "unaffected" for, as mentioned, even the temporary ameliorations in temperature and subjective symptoms we are inclined to regard as beneficial. In a number of these cases it will be seen from the remarks on Table 2 that the fever ran permanently lower after treatment. In other cases the bacteria were diminished or disappeared from the blood. It is, moreover, distinctly to be noted that in none of these cases did the use of vaccine apparently weaken the patient or contribute in any demonstrable way to a fatal outcome when such occurred. (Fig. 1, Case 47).

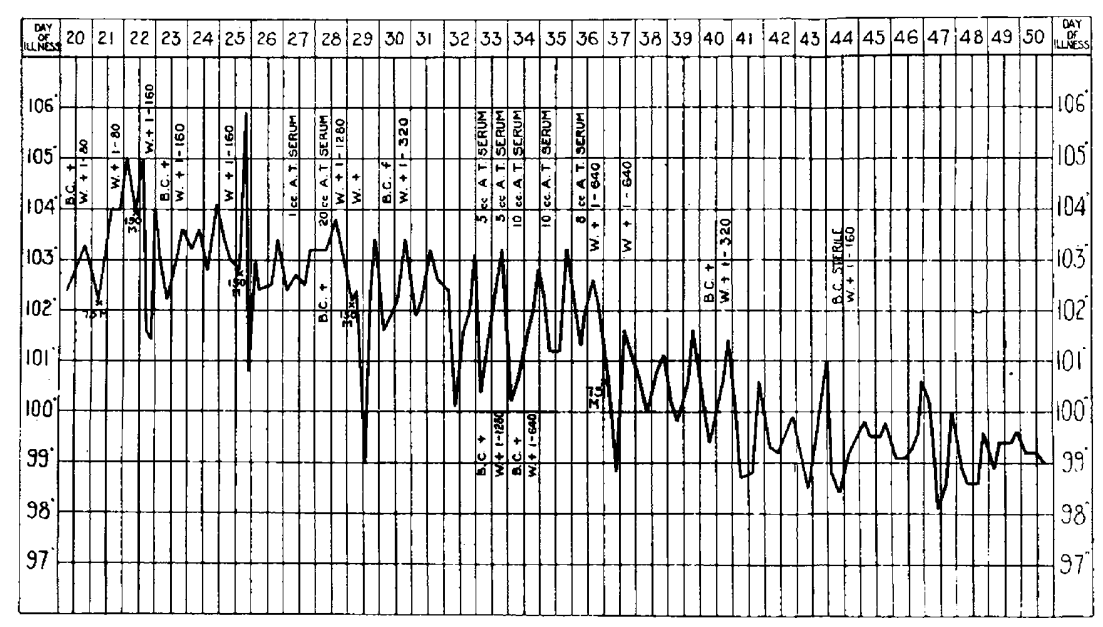

Fig. 1.-Temperature curve and other data in Case 47. The data in these charts are abbreviated as follows: B. C.=Blood culture; W.=Widal; A. T. Serum $=$ Antityphoid serum ; $75 \mathrm{M}=$ Sensitized vaccine corresponding to 75 million typhoid bacilli.

Group 2. Benefited Cases.-Of these cases there were thirteen, or 24.5 per cent. in our series. In these cases one or more doses of vaccine led not only to temporary amelioration but to a lytic type of defervescence, the successive drops in temperature being related directly to the vaccine treatments. In cases of this group the duration of the disease was apparently shortened and the course markedly ameliorated. (Fig. 2, Case 43).

Group 3. Aborted Cases.-Cases totaling twenty-two, or 41.5 per cent., of our series. In these cases the injection of vaccine led to a more or less critical fall of temperature directly associated with the vaccine injection. (Fig. 3, Case 35). 
TABLE 2.-Relatively Unaffected Cases

\begin{tabular}{|c|c|c|c|c|c|c|c|}
\hline No. & Age & Widal & $\begin{array}{l}\text { Blood } \\
\text { Cul- } \\
\text { ture }\end{array}$ & $\begin{array}{l}\text { Treat- } \\
\text { ment, }\end{array}$ & $\begin{array}{l}\text { Num- } \\
\text { ber } \\
\text { of } \\
\text { Treat- } \\
\text { ments }\end{array}$ & $\begin{array}{l}\text { Perma- } \\
\text { nent } \\
\text { Normal } \\
\text { Temp.,* } \\
\text { Day }\end{array}$ & Remarks \\
\hline 2 & 14 & 0 & 0 & 14 & 7 & $\begin{array}{l}\text { Died } 32 d \\
\text { day }\end{array}$ & $\begin{array}{l}\text { Severe case complicated by laryngeal } \\
\text { symptoms. Necropsy refused. }\end{array}$ \\
\hline 6 & 20 & +80 & + & 6 & 4 & 38 & $\begin{array}{l}\text { Severe case. White count rose from } \\
8,000 \text { to } 21,000 \text { after vaccine treat- } \\
\text { ment. }\end{array}$ \\
\hline 11 & 7 & + & + & 5 & 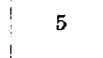 & 28 & $\begin{array}{l}\text { Severe case. Delirium. Abdominal } \\
\text { pain. }\end{array}$ \\
\hline 12 & 5 & + & + & 7 & 4 & 29 & $\begin{array}{c}\text { Severe case. Delirium. Abdominal } \\
\text { pain. }\end{array}$ \\
\hline 13 & 25 & + & + & 15 & 3 & 30 & $\begin{array}{l}\text { Severe case. Temperature distinctly } \\
\text { lower following vaccine treatment, } \\
\text { but course of disease not shortened. }\end{array}$ \\
\hline 14 & 20 & +50 & + & 15 & 5 & 48 & $\begin{array}{l}\text { Severe case. No effect on temperature } \\
\text { course. }\end{array}$ \\
\hline 16 & 45 & + & + & 12 & 5 & 49 & $\begin{array}{l}\text { Severe case. No effect on temperature } \\
\text { course. }\end{array}$ \\
\hline 18 & 30 & +320 & + & 15 & 4 & 45 & $\begin{array}{l}\text { Severe case. Temporary effect on } \\
\text { temperature course. }\end{array}$ \\
\hline 20 & 35 & 0 & + & 7 & 2 & $\begin{array}{l}\text { Died loth } \\
\text { day }\end{array}$ & $\begin{array}{l}\text { Severe. Very toxic. Patient uncon- } \\
\text { scious when first seen. }\end{array}$ \\
\hline 44 & 22 & +40 & + & 14 & 4 & 52 & $\begin{array}{l}\text { Moderately severe. slight symptom- } \\
\text { atic improvement following injec- } \\
\text { tion of vaccine. }\end{array}$ \\
\hline 47 & 62 & +80 & + & 21 & 6 & 48 & $\begin{array}{l}\text { Severe case. Blood culture positive } \\
\text { to fortieth day of disease. }\end{array}$ \\
\hline 48 & 14 & 0 & + & 21 & 1 & $\begin{array}{l}\text { Died } 26 \text { th } \\
\text { day }\end{array}$ & $\begin{array}{l}\text { Severe case. Toxic. Organism from } \\
\text { blood at first inagglutinable. Ex- } \\
\text { sanguinating hemorrhage. }\end{array}$ \\
\hline 57 & 56 & $+1,280 \dagger$ & + & 21 & 1 & $\begin{array}{l}\text { Died } 27 \mathrm{th} \\
\text { day }\end{array}$ & $\begin{array}{l}\text { Severe case. Temperature normal after } \\
\text { vaccine treatment. Died six days } \\
\text { later from hemorrhage and perfora- } \\
\text { tion. }\end{array}$ \\
\hline 61 & 19 & +320 & + & .14 & 5 & 43 & $\begin{array}{l}\text { Severe case. Muscle spasm. One col- } \\
\text { ony B. typhosus per c.c. blood on } \\
\text { twenty-second day. Blood sterile } \\
\text { three days later following combined } \\
\text { vaccine and serum treatment. }\end{array}$ \\
\hline 66 & 55 & +40 & + & $\dot{s}$ & 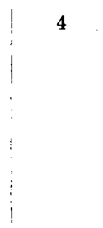 & $\begin{array}{c}\text { Died } 30 \text { th } \\
\text { day }\end{array}$ & $\begin{array}{l}\text { Severe case. Muscle spasm. Blood } \\
\text { culture positive on twenty-fifth day } \\
\text { of disease. Three hours after hem- } \\
\text { orrhage and perforation took place, } \\
\text { patient was operated on and perfo- } \\
\text { ration closed. Patient's general con- } \\
\text { dition was so serious that death fol- } \\
\text { lowed in spite of there being prac- } \\
\text { tically no gross soiling of the perl- } \\
\text { toneal cavity. }\end{array}$ \\
\hline 72 & 20 & +160 & + & 11 & 4 & 57 & $\begin{array}{l}\text { Severe case; three colonies B. typhosus } \\
\text { in } 1 \text { c.c. blood on eleventh day. } \\
\text { Blood sterile ten days later, follow- } \\
\text { ing serum and vaceine treatment. } \\
\text { Relapse began on thirty-first day, } \\
\text { lasting until fifty-seventh day. }\end{array}$ \\
\hline 75 & 46 & +80 & + & 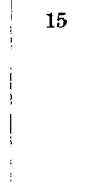 & 5 & 35 & $\begin{array}{l}\text { Severe case; one colony B. typhosus } \\
\text { in } 2 \text { c.c. blood on nineteenth day. } \\
\text { Positive with } 1 \text { e.c. blood until } \\
\text { twenty-eighth day. Blood sterile on } \\
\text { thirty-frst day and defervescence } \\
\text { occurred four days later. Hyper- } \\
\text { leukocytic crisis } 17,000 \text { to } 18,000 \text { after } \\
\text { vaccine treatment. }\end{array}$ \\
\hline 79 & 19 & +320 & + & 5 & 4 & 29 & $\begin{array}{l}\text { Severe case. Toxic and comatose. } \\
\text { Symptomatically improved by treat- } \\
\text { ment but course not notably short- } \\
\text { ened. }\end{array}$ \\
\hline & 28 & 114 & $95 \%$ & 13 & 4 & 41 & \\
\hline
\end{tabular}

* A temperature below 100 F. by rectum for entire day. the patient's temperature down about three degrees during three days. He died three days later of perforation. This widal titer is therefore not included in the average. 
TABLE 3.-Benefited Cases

\begin{tabular}{|c|c|c|c|c|c|c|c|c|}
\hline No. & Age & Widal & $\begin{array}{l}\text { Blood } \\
\text { Cul- } \\
\text { ture }\end{array}$ & $\begin{array}{l}\text { Treat- } \\
\text { ment, } \\
\text { Day }\end{array}$ & $\begin{array}{l}\text { Num- } \\
\text { ber } \\
\text { of } \\
\text { Treat- } \\
\text { ments }\end{array}$ & $\begin{array}{l}\text { Perma- } \\
\text { nent } \\
\text { Normal } \\
\text { Temp., } \\
\text { Day }\end{array}$ & $\begin{array}{l}\text { Dura- } \\
\text { tion of } \\
\text { Treat- } \\
\text { ment, } \\
\text { Days }\end{array}$ & Remarks \\
\hline 23 & 21 & +160 & + & 6 & 2 & 21 & 15 & $\begin{array}{l}\text { Laboratory infection. Blood } \\
\text { culture positive fourth day. } \\
\text { Symptomatically well on thir- } \\
\text { teenth day. Afternoon rise } \\
\text { in temperature for several } \\
\text { days thereafter. }\end{array}$ \\
\hline 32 & 10 & $+1,280$ & + & 11 & 3 & 32 & 21 & $\begin{array}{l}\text { Severe ease. Very toxic. } \\
\text { Treatment very cautious be- } \\
\text { cause of slight intestiual } \\
\text { hemorrhage. }\end{array}$ \\
\hline 38 & 18 & +40 & + & 9 & 3 & 27 & 18 & $\begin{array}{l}\text { Severe case. Toxic, with mus. } \\
\text { cular spasticity. Blood cul- } \\
\text { ture positive after three } \\
\text { vaccine treatments. }\end{array}$ \\
\hline 39 & 8 & +160 & + & 11 & 5 & 30 & 19 & $\begin{array}{l}\text { Severe case. Complicated by } \\
\text { pyelitis. W. B. C. rose to from } \\
10,300 \text { to } 25,000 \text { after each } \\
\text { vaceine treatment. }\end{array}$ \\
\hline 42 & 23 & +160 & + & 13 & 4 & 26 & $1 \hat{s}$ & $\begin{array}{l}\text { Moderately severe. Marked } \\
\text { diarrhea. W. B. C. rose from } \\
7,800 \text { to } 16,250 \text { after vaccine } \\
\text { treatment. }\end{array}$ \\
\hline 43 & 25 & +80 & 0 & 16 & 2 & 26 & 10 & Mild case. \\
\hline 46 & 24 & +40 & + & 11 & 3 & 28 & 17 & $\begin{array}{l}\text { Severe case. Blood culture } \\
\text { sterile three days after com- } \\
\text { bined vaccine and serum } \\
\text { treatment. }\end{array}$ \\
\hline 49 & 28 & +40 & + & 15 & 3 & 34 & 19 & $\begin{array}{l}\text { Severe case. Blood culture } \\
\text { sterile } 72 \text { hours after frrst } \\
\text { vaccine treatment. Symptom. } \\
\text { atically well twenty-third } \\
\text { day. Leukocytes rose from } \\
7,400 \text { to } 15,200 \text { after treatment. }\end{array}$ \\
\hline 50 & 7 & +40 & + & 16 & 1 & 28 & 12 & $\begin{array}{l}\text { Severe case. Toxic and dis- } \\
\text { tended. }\end{array}$ \\
\hline 74 & 26 & +160 & + & 18 & 3 & 30 & 12 & $\begin{array}{l}\text { Moderately severe. Blood cul- } \\
\text { ture positive twenty-seconu } \\
\text { day. Hyperleukocytic erisis } \\
\text { of i5,200 after vaccine treat- } \\
\text { ment. }\end{array}$ \\
\hline 81 & 35 & +80 & $\mathbf{0}$ & 11 & 3 & 21 & 10 & Mild case. \\
\hline 94 & 30 & +80 & + & 7 & 3 & 23 & 16 & $\begin{array}{l}\text { Moderately severe. Blood cul- } \\
\text { ture sterile four days after } \\
\text { second vaceine treatment. }\end{array}$ \\
\hline 104 & 23 & +50 & + & 18 & 2 & 28 & 10 & Moderately severe. \\
\hline & 21 & +182 & $84.6 \%$ & 12.4 & 2.8 & 27 & 14.7 & \\
\hline
\end{tabular}


TABle 4.-Abortively Recovered Cases

\begin{tabular}{|c|c|c|c|c|c|c|c|c|}
\hline No. & Age & Widal & $\begin{array}{l}\text { Blood } \\
\text { Cul- } \\
\text { ture }\end{array}$ & $\begin{array}{l}\text { Treat- } \\
\text { ment, } \\
\text { Day }\end{array}$ & $\begin{array}{l}\text { Num- } \\
\text { ber } \\
\text { of } \\
\text { Treat- } \\
\text { ments }\end{array}$ & $\begin{array}{c}\text { Perma- } \\
\text { nent } \\
\text { Normal } \\
\text { Temp., } \\
\text { Day }\end{array}$ & $\begin{array}{l}\text { Dura- } \\
\text { tion of } \\
\text { Treat- } \\
\text { ment, } \\
\text { Days }\end{array}$ & Remarks \\
\hline 1 & 70 & + & $\cdots$ & 12 & 1 & 18 & 6 & $\begin{array}{l}\text { Temperature had ranged from } \\
100 \text { to } 103 \text { for ten days previ- } \\
\text { ous to vaccine treatment. }\end{array}$ \\
\hline 5 & 30 & $+1-80$ & 0 & 5 & 3 & 21 & 16 & $\begin{array}{l}\text { Severe case. Hyperleukocyto- } \\
\text { sis of } 20,200 \text { following injec- } \\
\text { tion of vaccine. }\end{array}$ \\
\hline 10 & 14 & + & $\cdots$ & 10 & 1 & 16 & ; & Moderately severe case. \\
\hline 21 & 53 & +640 & 0 & 15 & 2 & 21 & 6 & Mild. \\
\hline 26 & 14 & + & $\ldots$ & 16 & 2 & 23 & 7 & Mild. \\
\hline 27 & 38 & +160 & + & 10 & 3 & 19 & 9 & $\begin{array}{l}\text { Blood cultures sterile } 24 \text { and } \\
96 \text { hours after vaccine treat- } \\
\text { ment. W. B. C. } 4,000 \text { to } 14,000 \text {. }\end{array}$ \\
\hline 31 & 19 & +320 & 0 & 10 & $\mathbf{1}$ & 15 & 5 & Mild. \\
\hline 33 & 15 & +320 & 0 & 15 & 2 & 24 & 9 & Moderately severe. \\
\hline 34 & 6 & +320 & 0 & 14 & 1 & 18 & 4 & Mild. \\
\hline 35 & 28 & +160 & + & 7 & 2 & 13 & 6 & $\begin{array}{l}\text { Blood cultures sterile } 24 \text { and } \\
48 \text { hours after vaccine treat- } \\
\text { ment. }\end{array}$ \\
\hline 40 & 20 & +640 & 0 & 14 & 2 & 22 & 8 & $\begin{array}{l}\text { Mild. Accompanied by pro- } \\
\text { fuse perspiration. }\end{array}$ \\
\hline 41 & 8 & +160 & 0 & 18 & 2 & 26 & 8 & Mild. \\
\hline 51 & 5 & +20 & 0 & 6 & 1 & 8 & 2 & $\begin{array}{l}\text { Mild. Two of three children } \\
\text { ill at same time. Blood cul- } \\
\text { ture positive in one case. }\end{array}$ \\
\hline 52 & 4 & +10 & 0 & 6 & 1 & 11 & 5 & $\begin{array}{l}\text { Mild. Two of three children } \\
\text { ill at same time. Blood cul- } \\
\text { ture positive in one case. }\end{array}$ \\
\hline 59 & 5 & +20 & + & 10 & 2 & 16 & 6 & $\begin{array}{l}\text { Moderately severe. Blood cul. } \\
\text { ture sterile four days after } \\
\text { first treatment. }\end{array}$ \\
\hline 63 & 38 & +160 & 0 & 17 & 2 & 23 & 6 & Moderately severe. \\
\hline 70 & 21 & +160 & + & 81 & 3 & 18 & 10 & $\begin{array}{l}\text { Delirious, severe headache. } \\
\text { Blood culture sterile } 48 \text { hours } \\
\text { after first treatment. }\end{array}$ \\
\hline 73 & 30 & $+1,280$ & + & 32 & 3 & 40 & 8 & $\begin{array}{c}\text { Comatose and involuntary. } \\
\text { Pulse } 130 .\end{array}$ \\
\hline 80 & 14 & +160 & 0 & 26 & 1 & 35 & 9 & Moderately severe. \\
\hline 90 & 8 & +40 & + & 10 & 2 & 23 & 13 & $\begin{array}{l}\text { Blood culture sterile five days } \\
\text { after flrst treatment. None } \\
\text { taken between. }\end{array}$ \\
\hline 95 & 25 & + & + & 12 & 2 & 21 & 9 & Moderately severe. \\
\hline $103^{*}$ & 30 & $+1-40$ & + & 8 & 3 & 11 & 3 & Severe. \\
\hline i & 22.5 & 260 & $42 \%$ & 12.7 & $2-$ & 20 & 7.3 & \\
\hline
\end{tabular}

* Case of paratyuhold "B". 
A consideration of our cases as arranged in these three groups brings out a number of interesting correlations. (Tables 2, 3 and 4).

We see, for instance, that the treatment was begun on the average on about the same day in all three categories (12 to 13) and that the average age of the patients was nearly the same. The first group of "Relatively Unaffected Cases" differs distinctly from the "Abortively Recovered" ones in that the blood cultures were positive in over twice as many cases in the first ( 95 per cent. as compared with 42 per cent.) and again in the fact that the Widal was much lower on the average in the unaffected cases than in the aborted cases ( 1 to 114 and 1 to 260).

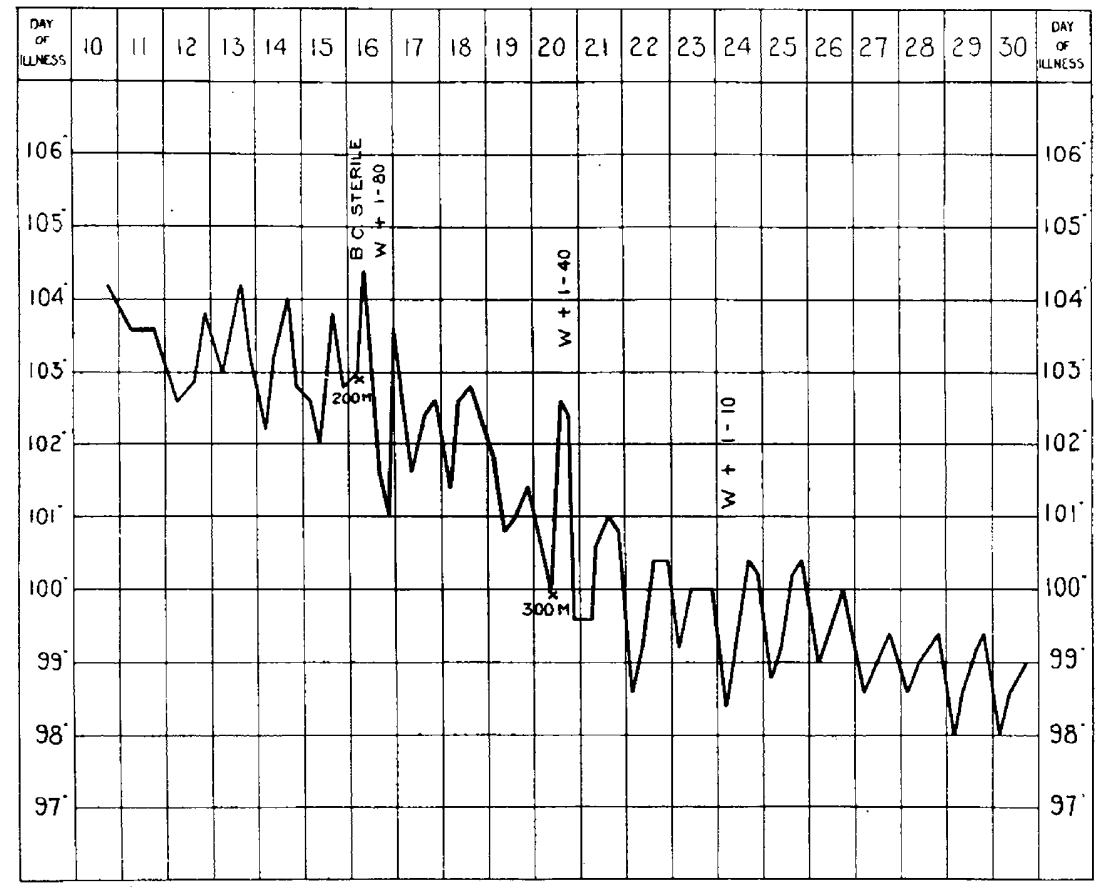

Fig. 2.-Temperature curve and other data in Case 43

The benefited cases (Group 2) lie intermediate between the two, having nearly as high a percentage of blood cultures as Group 1 and nearly as high a Widal average as Group 3.

There is little doubt that the number of typhoid bacilli in the circulating blood bears a distinct relation to the severity of the course of the disease, and the persistence of positive blood cultures indicates an unfavorable outcome (see particularly Schottmüller, ${ }^{50}$ Jochmann $^{51}$ ).

50. Schöttmüller, H.: Die Typhosen Erkrankungen, Handb. der inn. Med., 1912, I, Mohr and Staehelin.

51. Jochmann: Lehrbuch der Infektionskrankheiten, Springer, Berlin, 1914. 
Conversely the disappearance of the bacteriemia early in the disease is a favorable indication. From such facts we should expect to find the third group of cases in a general way milder than Group 1.

Whereas it is impossible to judge what the outcome of any one of our cases would have been without treatment, certain impressions of the severity of the cases before treatment in relation to the outcome may be of interest (Table 5).

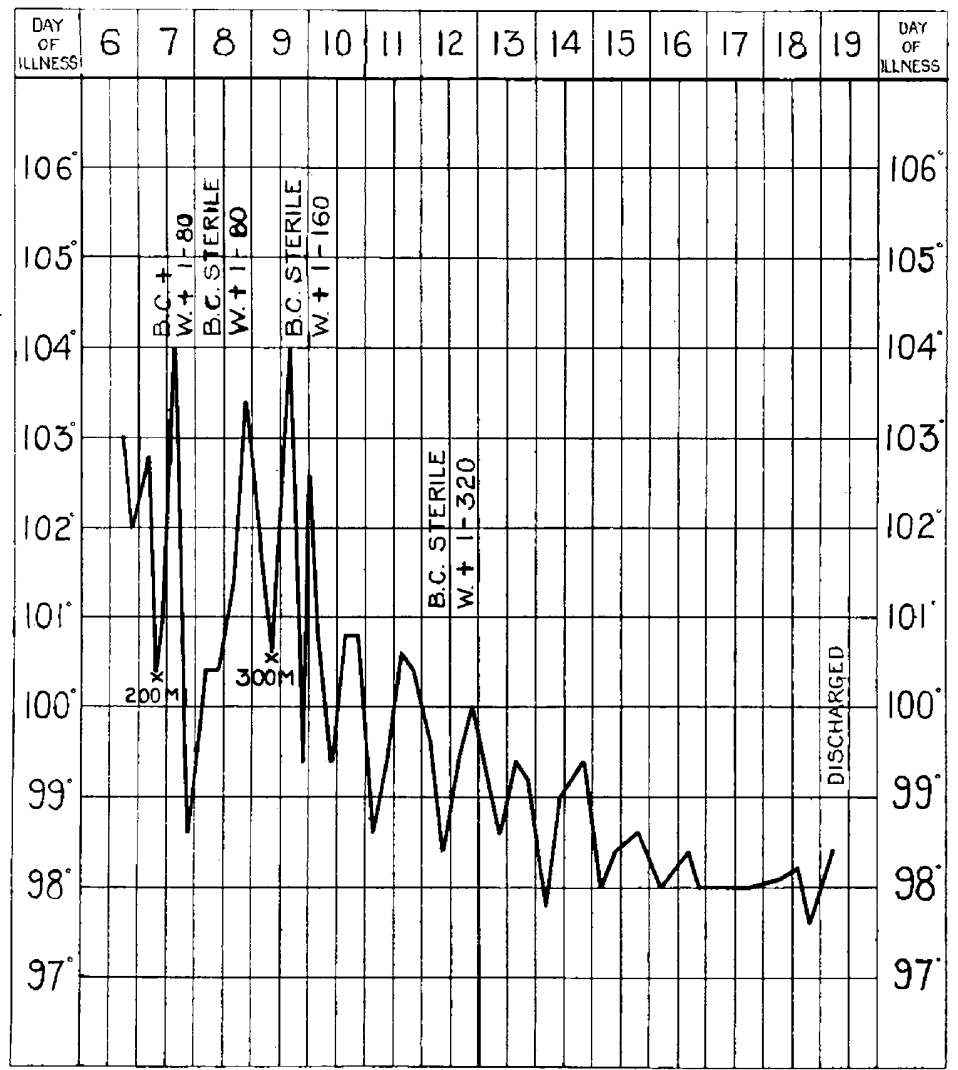

Fig. 3.-Temperature curve and other data in Case 35.

TABle 5.-General Condition of the Cases Before Treatment

Group 1, unaffected..

Group 2, benefited .

Severe

Group 3, aborted...

15

6

Moderate

3
5
7

Mild

It is evident that the milder cases were more likely to be favorably affected by treatment than the severe ones. In this connection it may be wise to forestall criticisms that might be made to our interpretation of the abrupt recoveries as due to the injection of vaccine. It may be suggested by clinicians with an extensive experience in typhoid fever 
that they have seen cases (usually a case) in which the temperature fell by crisis in typhoid fever without treatment. We have been able to find little detailed account of such a course in the literature. McRae ${ }^{52}$ in his carefully analyzed series of 1,500 cases noted a critical fall in two cases only ( 0.1 per cent.). He further notes a mild form of typhoid in 44 cases ( 3 per cent.). These figures added or separately, may be compared with our 41.5 per cent. of rapid recoveries. Of further significance is the direct relation of the vaccine injection to the result

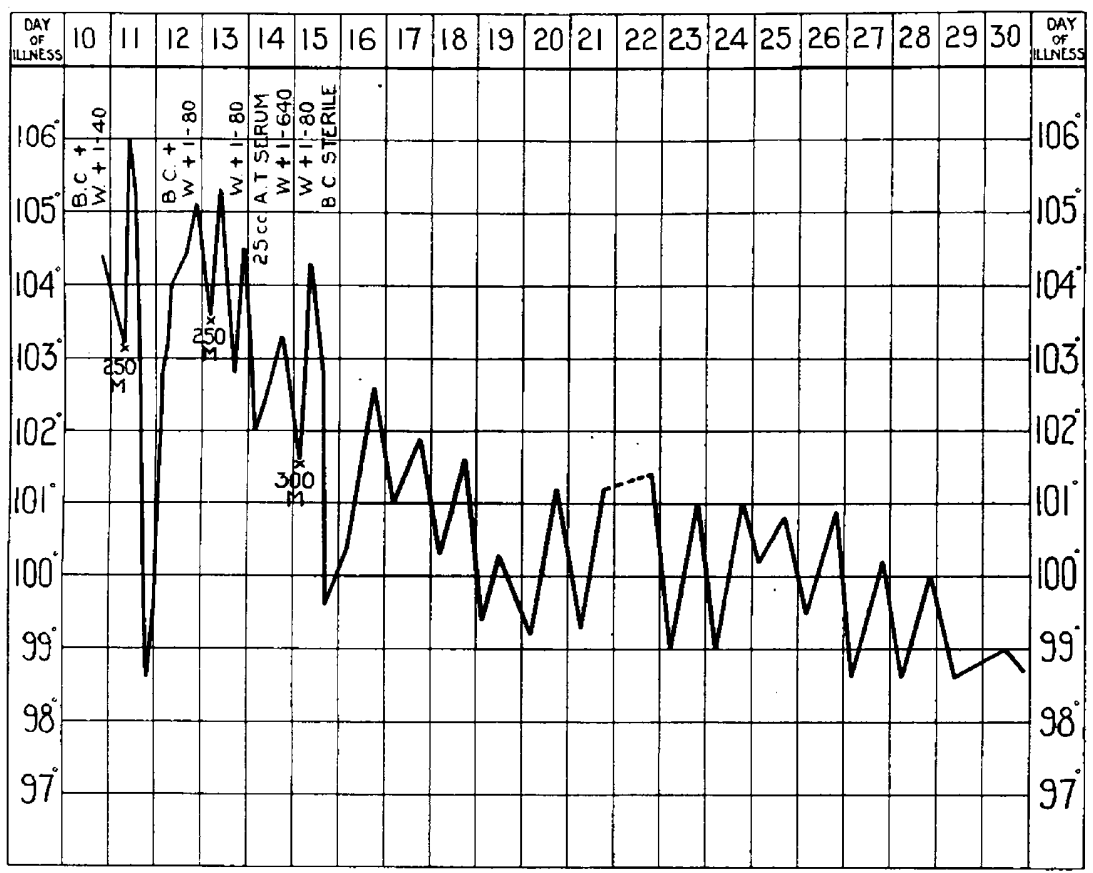

Fig. 4.- Temperature curve and other data in Case 46.

produced and the fact that the average duration of the specific treatment until a permanent normal temperature was reached was a little over seven days.

In this connection it may be of interest to contrast the average duration of the disease in the three categories as compared with McCrae's figures (Table 6).

table 6.-Duration of Disease as Contrasted with McCrae's Figures

Group 1, unaffected..................4 41 days

Group 2, benefited.................... 27 days

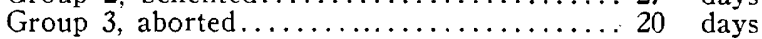

Real average $\ldots \ldots \ldots \ldots \ldots \ldots \ldots .27 .6$ days

Average of McCrae's 1,500 cases..... 31 days

52. McCrae: Osler's System of Medicine, Ed. 1, ii, 70. 
The relative intensity of the Widal reaction in the favorably affected cases as compared with the others seems to us of peculiar significance. It may be taken as an indication of the degree of successful response that the patient has made to the infection. We do not wish to assume that the agglutinin titer is any true measure of resistance, but it often runs parallel to those antibodies that are responsible for tipping the balance in the patient's favor. Our conception of the recovery that is favored by the intravenous injection of sensitized vaccine would be that it is due first to a hyperleukocytosis produced in maximum degree by the use of tropinized bacteria, and secondly to the action of the patient's own antibodies on the circulating bacteria. Such a conception to be proved would necessitate an estimation of the patient's tropins in relation to results produced rather than the agglutinins. The establishment of an accurate method for such determinations is at present engaging our attention.

A further corollary of this hypothesis should show that the bacteria in the patient's blood disappear or diminish in the presence of a hyperleukocytic rise and the simultaneous presence of suitable antibodies. This was found to be the case in rabbits in the experiments of Gay and Claypole. Although it has not been possible to take an extensive series of blood cultures in many of our cases, our results show that in ten cases positive blood cultures became sterile in from one to three days after injection of vaccine. We contemplate a more extensive series in this direction. In addition to diminishing the bacteremia or actually sterilizing the patients, as would seem to be the case in many of our abortively recovered cases, the injection of sensitized vaccine in the majority of cases is accompanied by an increase of the Widal titer which, as we have seen, is of favorable prognostic significance.

In view of the probable mechanism of recovery in typhoid fever induced by the intravenous injection of sensitized vaccine, it might seem reasonable in those cases associated with a low Widal titer in which less favorable results may be anticipated, to supply the necessary antibodies artificially. This could be done by the use of an immune serum. One is not impressed with the results hitherto attained in the serum therapy of typhoid (Chantemesse, ${ }^{53}$ Rodet, ${ }^{54}$ Rodet and Lagriffoul, ${ }^{55}$

53. Chantemesse, M.: Toxine typhoide soluble et serum antitoxique de la fiévre Typhoide, Prog. méd., 1898, Series 3, vii, 245.

54. Rodet, A.: Die Serotherapie beim Typhus, Handb. der serum Therapie, A. Wolf-Eisner, München, 1910.

55. Rodet, A., and Lagriffoul: La Serotherapie de la Fiévre Typhoide, Presse méd., 1910, xviii, 969. 
Lüdke, ${ }^{56}$ Andriescu and Ciuca, ${ }^{57}$ and Koenigsfeld ${ }^{58}$ ). We have no certainty whether such a serum should be antiendotoxic, or according to our Dwn working hypothesis, largely tropic. While waiting for further experimental evidence on this point we have felt justified in certain of our cases, particularly in those with a low Widal, in giving intravenous injections of the serum of goats that had received repeated subcutaneous and intravenous injections of several strains of living B. typhosus. Whereas the result with such serums has not been in many instances striking, it has at all events shown the harmlessness of goat serum even when given in fairly large quantities intravenously.

Fresh goat serum was first shown to have no hemolytic or hemagglutinative effect on human blood corpuscles. In each case where intravenous injection was intended 1 c.c. of goat serum (either normal or immune) was given subcutaneously twenty-four hours previously to avoid possible anaphylactic shock. In all eight cases were given intravenous injections ranging from 20 to 95 c.c. In no instance was any untoward immediate symptom noted, and in only one case was a slight urticaria found subsequently. This latter finding may be contrasted with the usual results which follow the intravenous injection of large amounts of immune serums from the horse $\left(\mathrm{Cole}^{59}\right)$. In all instances, as expected, the infusion of a relatively considerable amount of antiserum caused an immediate rise of the agglutinins in the patient and in several instances the serum injection alone seemed followed by a symptomatic improvement and slight defervescence.

In one case (Fig. 4, Case 46) which we trust will not prove to be exceptional, two injections of vaccine in a patient with low Widal and positive culture early in the disease (tenth day) were followed by persistent positive cultures and only temporary temperature fall. The administration of 25 c.c. of antityphoid serum intravenously followed the next day by a third dose of vaccine, led to sterilization of the blood stream and immediate defervescence. In this case at least it seems evident that the cure was due to the mixed serum and vaccine treatment.

56. Ludke, H.: Die Serumtherapie des Abdominal typhus, München. med. Wchnschr., 1912, xxv, 907; Die Behandlung des Abdominal typhus mit Intravenosen Injektionen von Albumosen, München. med. Wchnschr., 1915, xxviii, 321.

57. Andriescu, C., and Ciuca, M.: De l'action du Serum antityphique de Besredka sur l'evolution de la fiévre Typhoide, Ann. de l'Inst. Pasteur, 1913, xxvii, 170.

58. Koenigsfeld, H.: Ein neues Prinzip der Serumtherapie bei Infektionskrankheiten mit besonderer Berucksichtigung des Typhus abdominalis, München. med. Wchnschr., 1915, 1xii, 253.

59. Cole, R.: Pneumococcus Infection and Lobar Pneumonia, The Archives INT. MEd., 1914, xiv, 56. 


\section{FATAL CASES}

It will be seen from Table 2, comprising our relatively unaffected cases, that there have been five fatal cases in our treated series, or a little over 9 per cent., which does not differ from McCrae's large series with the same mortality. Of course no mortality average is of great significance in so small a series as our own. It is to be noted that a disproportionate number of our cases have died from the "accidents" of typhoid, if we may so call them. There was hemorrhage in three cases, two of which were followed by perforation. These two complications should account for death in 40 per cent. of the cases according to McCrae. In our own series they represent 60 per cent. of the fatalities. It should be noted that in two of these cases the treatment was not begun until the twenty-first day. True typhoid toxemia was the cause of death in only one of our cases (20). Case 2 was toxic, but probably died of some laryngeal complication; necropsy was refused.

\section{RELAPSES}

There have been five relapses in our series ( 9 per cent.), somewhat lower than McCrae's average of 11.4 per cent. It should be noted that two relapses have occurred in our cases listed as abortively recovered after discharge from the hospital; both promptly responded to a single reinjection of vaccine. The early discharge of the patient we believe had a distinct influence on the occurrence of these relapses. During the latter part of our series we have followed the intravenous treatments with a series of three subcutaneous injections of the vaccine in the dosage ordinarily employed for prophylaxis $(1 / 10 \mathrm{mg}=750 \mathrm{million})$. In twelve cases in which this treatment has been fully carried out there have been no relapses, whereas the five relapses occurred in forty-one cases in which no such treatment was employed or completed. These subsequent subcutaneous injections may be followed by slight rise of temperature.

\section{SPECIFICITY OF TREATMEN'T EMPLOYED}

In view of the relative success that has been reported by means of certain nonspecific methods of treating typhoid fever, it may be well to express our conception of the relation of our method of treatment to such methods.

Early in the history of the treatment of typhoid by vaccines Rumpf ${ }^{2}$ questioned the specificity of the results claimed by Fraenkel ${ }^{1}$ on the ground that he had obtained similar favorable effects by the use of preparations of $B$. pyocyaneus. That such results were at least relatively less effective would seem to be shown from the subsequent work of Kraus and Buswell ${ }^{3}$ and Presser. ${ }^{4}$ Kraus $^{60}$. has obtained abortive

60. Kraus, R.: Ueber Bakteriotherapie akuter Infektionskrankheiten, Wien. klin. Wchnschr., 1915, xxviii, 29. 
cures in typhoid by the use of colon vaccines. Ichikawa has cured paratyphoid, as we did, by sensitized typhoid vaccine. Lüdke ${ }^{55}$ has mentioned favorable results by the simple use of a deutero-albumose. Letulle and Mage ${ }^{61}$ and Gay ${ }^{62}$ have treated cases of typhoid by means of a preparation of colloidal gold (colibiase). We believe such favorable results, which we are quite ready to accept, are in reality in perfect harmony with each other and with our own choice of treatment. All of these substances including colloidal gold $^{63}$ produce hyperleukocytosis, particularly when injected into the circulation. Leukocytic extracts probably act in the same way in those cases in which they are undoubtedly effective. Any of these substances could therefore be expected to cure a percentage of cases of typhoid owing to the dual mechanism of a hyperleukocytosis plus antibodies in the patient.

Intravenous treatment by means of sensitized typhoid bacilli differs from the above methods in two ways:

1. Owing to the fact that the injected protein is sensitized or tropinized, the response on the part of the leukocytes is much more intense and effective (Gay and Claypole ${ }^{12}$ ).

2. Typhoid vaccine aids in building up the active immunity of the patient against typhoid fever as no other preparation can.

\section{SUMMARY}

This article deals with the study of 105 cases of suspected typhoid fever in which we were allowed to examine the patients through the great courtesy of a number of physicians in Alameda and San Francisco Counties. Thorough laboratory examinations in most of these cases by blood cultures and Widal tests and in a number the search for the typhoid bacilli in the stools and urine, offer certain facts of interest in the differential diagnosis of typhoid fever. In 65 of the 105 cases the diagnosis of typhoid fever was made from both clinical and laboratory data. In these 65 cases the Widal was positive in 60 (93.7 per cent.) and as early as the fifth day, the high percentage of results being due, in a large measure, to the method employed, namely, the use of the macroscopic method and a formaldehydized culture of the typhoid bacillus. Of the blood cultures taken in 58 cases there were 40 positive ( 70 per cent.), including a case first seen on the thirty-second day. In only one case of the 65 were both Widal and

61. Lutelle, M., and Mage: Traitément la Fiévre Typhoide par l'or colloidal en injections intraveineuses, Bull. de l'Acad. méd., Paris, 1914, Ixxii, 421.

62. Gay: Un Traitément pratique de la fiévre typhoide aux armees, Presse méd., March 4, 1915, p. 67.

63. See discussion by Robin and Chantemesse in loc. cit., Ref. 60. 
blood culture negative, which case was diagnosed by the presence of $B$. typhosus in the stools.

Of the 40 cases excluded as not being typhoid fever on a laboratory basis, 36 could ultimately be excluded on both clinical and further laboratory examination. There remain 4 cases which on clinical evidence alone may have been typhoid, but which are not included in our series owing to the fact that laboratory proof was lacking. It may incidentally be remarked that 2 of these cases were treated by the method described, with abrupt recovery. Of the 65 cases it was impossible for various reasons that are stated, to treat 12 . The remainder of the cases, however, were all treated without choice.

There remain, then, a series of fifty-three cases of typhoid fever in which the diagnosis was absolutely certain both on clinical and laboratory grounds. We have not attempted to influence the ordinary symptomatic treatment of these cases, which differs as much as might be expected in a group of over fifty physicians. The patients, moreover, were cared for under varying conditions in private homes and hospitals, some of them even without the attention of a trained nurse. This variation in care and location of the cases had undoubtedly an effect on the mortality and has made thorough laboratory examinations, such as leukocyte counts at frequent intervals, impossible in all the cases.

The mortality in these cases has been precisely what one would expect under the best hospital conditions (McCrae), namely 9 per cent., which we regard as suggesting that, under uniform conditions, with our method of treatment the mortality would have been less than the average. The mortality has been composed, to a large extent, of what may be termed the "accidents" of typhoid, namely 60 per cent. of the deaths by hemorrhage or perforation.

Our method of treatment has consisted in the intravenous injection of $1 / 50$ to $1 / 25$ milligram ( 150 to 300 million bacteria) of a sensitized, polyvalent, killed typhoid vaccine sediment prepared after the method of Gay and Claypole. This injection gives rise to a series of symptoms characterized particularly by a chill, rise and fall of temperature and leukopenia followed by hyperleukocytosis. The fall of temperature with its attendant hyperleukocytosis leaves the patient at least temporarily benefited, and the benefit and normal temperature may be permanent. Thus in 66 per cent. of the cases a distinct benefit was obtained, as shown by lowered temperature, disappearance or amelioration of subjective symptoms and an apparently accelerated recovery. In 41.5 per cent. of this 66 per cent. the recovery was of an abortive form with a critical fall of temperature and a permanent normal temperature established within a few days. This permanent normal tem- 
perature was reached on an average seven days after beginning treatment in these cases. There remains, however, 34 per cent. of cases which are classified as relatively unaffected. We regard this classification as underestimating the beneficial results for reasons given. In none of the cases did the use of the vaccine have any apparent harmful effect on the case, although in four, in which too large a dose was used, the symptoms were somewhat alarming.

A series of subcutaneous injections following the intravenous treatment apparently aids in preventing relapses.

We regard the mechanism of benefit and cure in these cases which were affected by the treatment as due to a combination of specific hyperleukocytosis and the presence of antibodies (tropins?) in the patient's blood. The injection of vaccine could be shown in a number of cases to be followed by the disappearance or diminution of bacteremia and usually also by an increase in the Widal. In those cases which did best the Widal was originally high and those cases which showed the least effect had the low Widals. The cases judged as "mild" before treatment began did better on the whole than those regarded as "severe." There were, however, a number of severe cases which showed abrupt recovery or benefit.

On the hypothesis that successful results are due to the strength of the antibodies already established in the patient, we have ventured in severe cases with low antibody content, to combine with the vaccine treatment the intravenous injection of considerable amounts of typhoid immune serum from goats. These cases, although few in number, suggest that this type of treatment with further elaboration might increase the percentage of favorable results.

We regard the use of sensitized vaccine as being better for intravenous injection than plain typhoid vaccine or less specific methods of treatment that have been suggested by other authors, owing to the fact that sensitized typhoid vaccine produces a specific form of hyperleukocytosis of maximum degree (Gay and Claypole), and may also be shown to be followed by an increase in active immunity of the patient against the disease. 